\title{
Internal Transcribed Spacer Regions 1 and 2 and Random Amplified Polymorphic DNA Analysis of Didymella bryoniae and Related Phoma Species Isolated from Cucurbits
}

\author{
Benesh M. Somai, Ralph A. Dean, Mark W. Farnham, Thomas A. Zitter, and Anthony P. Keinath
}

First author: Department of Microbiology, University of Durban-Westville, Private Bag X54001, South Africa; second author: Fungal Genomics Laboratory, North Carolina State University, Raleigh 27695; third author: U.S. Department of Agriculture, U.S. Vegetable Laboratory, Charleston, SC 29414; fourth author: Department of Plant Pathology, Cornell University, Ithaca, NY 14853; and fifth author: Department of Plant Pathology and Physiology, Clemson University, Coastal Research and Education Center, Charleston, SC 29414. Accepted for publication 7 May 2002.

\begin{abstract}
Somai, B. M., Dean, R. A., Farnham, M. W., Zitter, T. A., and Keinath, A. P. 2002. Internal transcribed spacer regions 1 and 2 and random amplified polymorphic DNA analysis of Didymella bryoniae and related Phoma species isolated from cucurbits. Phytopathology 92:997-1004.

Didymella bryoniae (anamorph Phoma cucurbitacearum) is the causal agent of gummy stem blight, although other Phoma species are often isolated from cucurbit plants exhibiting symptoms of the disease. The molecular and phylogenetic relationships between $D$. bryoniae and these Phoma species are unknown. Isolates of D. bryoniae and Phoma obtained from cucurbits grown at various geographical locations in the United States were subjected to random amplified polymorphic DNA (RAPD) analysis and internal transcribed spacer (ITS) sequence analysis (ITS-1 and ITS-2) to determine the molecular and phylogenetic relationships

within and between these fungi. Using RAPD fingerprinting, 59 isolates were placed into four phylogenetic groups, designated RAPD group (RG) I, RG II, RG III, and RG IV. D. bryoniae isolates clustered in either RG I (33 isolates), RG II (12 isolates), or RG IV (one isolate), whereas all 13 Phoma isolates clustered to RG III. There was greater than $99 \%$ sequence identity in the ITS- 1 and ITS- 2 regions between isolates in RG I and RG II, whereas isolates in RG III, P. medicaginis ATCC 64481, and P. exigua ATCC 14728 clustered separately. On muskmelon seedlings, a subset of RG I isolates were highly virulent (mean disease severity was $71 \%$ ), RG II and RG IV isolates were slightly virulent (mean disease severity was $4 \%$ ), and RG III isolates were nonpathogenic (disease severity was $0 \%$ for all isolates). The ITS sequences indicate that RG I and RG II are both D. bryoniae, but RAPD fingerprints and pathogenicity indicate that they represent two different molecular and virulence subgroups.
\end{abstract}

Didymella bryoniae (Auersw.) Rehm, anamorph Phoma cucurbitacearum (Fr.:Fr.) Sacc., causes gummy stem blight (GSB) of cucurbits throughout the world $(20,27)$. The pathogen has a wide host range within the Cucurbitaceae, which includes cucumber (Cucumis sativus L.), muskmelon (Cucumis melo L.), watermelon (Citrullus lanatus (Thunb.) Matsum. \& Nakai), pumpkin and squash (Cucurbita spp.), and several wild cucurbits $(27,33)$. No host specificity has been observed among isolates from different cucurbit hosts $(12,13,36)$. Resistance to $D$. bryoniae is available in cucumber $(26,30)$, watermelon (18), and muskmelon (17); however, resistant cultivars have not performed well in commercial production (27). GSB has become more severe as genetic resistance to other cucurbit diseases has become more widely used $(26,29)$.

Few studies have examined the molecular and genetic characteristics of $D$. bryoniae. The pathogen is homothallic in nature (4) and produces pseudothecia and ascospores in culture $(6,33)$ and on infected host tissues $(24,33)$. Isolates from different cucurbit hosts exhibited few genetic differences when subjected to random amplified polymorphic DNA (RAPD) fingerprinting (12). Eight isolates of $D$. bryoniae did not show any differential virulence to a set of eight cucumber genotypes (28).

Species other than $D$. bryoniae have also been isolated from plant tissues exhibiting symptoms of GSB. P. exigua (Ascochyta

Corresponding author: A. P. Keinath; E-mail address: tknth@clemson.edu

Technical contribution 4726 of Agriculture and Forestry Research, Clemson University, Clemson, SC.

Publication no. P-2002-0717-03R

(C) 2002 The American Phytopathological Society phaseolorum) has been found on cucumber, muskmelon, and watermelon in North Carolina (10), and P. lagenariae has been isolated from pumpkin in New York (7). However, isolates of Phoma sp. recovered from cucurbits in South Carolina and New York did not produce symptoms in cucurbit seedlings inoculated with them $(12,36)$. The objective of this study was to address and clarify the genetic association between $D$. bryoniae and related Phoma isolates, using phylogenetic relationships based on RAPD markers and sequence information from the internal transcribed spacer (ITS) region of rDNA. RAPD markers and ITS data have proved useful for elucidating phylogenetic relationships in other fungi $(9,25)$, including teleomorphic fungi and related species in the same anamorph genus $(3,11,35)$.

\section{MATERIALS AND METHODS}

Fungal cultures. A total of 62 isolates of $D$. bryoniae and Phoma spp. were used in this study. Thirty-two isolates (with the prefix $\mathrm{C}$ or $\mathrm{W}$ ) were from South Carolina, collected from three fields on one farm on Edisto Island, Charleston County, in 1994 (Table 1). P. medicaginis ATCC 64481 and P. exigua ATCC 14728 were obtained from the American Type Culture Collection, Manassas, Virginia. Twenty-eight other isolates were provided by T. A. Zitter, including isolates from seven New York counties, Florida, North Carolina, Wisconsin, and Arizona (Table 1). All isolates except $P$. medicaginis and $P$. exigua were grown on one-quarter-strength potato-dextrose agar (QPDA) at $23^{\circ} \mathrm{C}$ with a 12 -h photoperiod for 2 weeks (12). Isolates were initially identified as either D. bryoniae or Phoma sp. by their mycelial growth rate and the size and shape of their conidia and ascospores (12). 
TABLE 1. Random amplified polymorphic DNA (RAPD) groups of isolates of Didymella bryoniae and Phoma used in this study

\begin{tabular}{|c|c|c|}
\hline Isolate $^{\mathrm{a}}$ & Host & Geographic origin ${ }^{b}$ \\
\hline \multicolumn{3}{|l|}{ RAPD group I } \\
\hline D. bryoniae C61 & Cucumber & South Carolina \\
\hline D. bryoniae $\mathbf{C 6 2}^{\mathrm{c}}$ & Cucumber & South Carolina \\
\hline D. bryoniae C64 & Cucumber & South Carolina \\
\hline D. bryoniae C66 & Cucumber & South Carolina \\
\hline D. bryoniae $\mathbf{C 6 8}$ & Cucumber & South Carolina \\
\hline D. bryoniae C69 & Cucumber & South Carolina \\
\hline D. bryoniae $\mathrm{C} 70$ & Cucumber & South Carolina \\
\hline D. bryoniae $\mathrm{C} 72$ & Cucumber & South Carolina \\
\hline D. bryoniae NY6 & Cucumber & New York \\
\hline D. bryoniae $\mathbf{C 4 5}$ & Muskmelon & South Carolina \\
\hline D. bryoniae $\mathrm{C} 46$ & Muskmelon & South Carolina \\
\hline D. bryoniae $\mathrm{C} 48$ & Muskmelon & South Carolina \\
\hline D. bryoniae $\mathrm{C} 49$ & Muskmelon & South Carolina \\
\hline D. bryoniae C51 & Muskmelon & South Carolina \\
\hline D. bryoniae C53 & Muskmelon & South Carolina \\
\hline D. bryoniae $\mathbf{C 7 6}$ & Muskmelon & South Carolina \\
\hline D. bryoniae C79 & Muskmelon & South Carolina \\
\hline D. bryoniae C81 & Muskmelon & South Carolina \\
\hline D. bryoniae $\mathrm{C} 82$ & Muskmelon & South Carolina \\
\hline D. bryoniae FL1 & Muskmelon & Florida \\
\hline D. bryoniae NY1 & Muskmelon & New York (4) \\
\hline D. bryoniae NY2 & Muskmelon & New York \\
\hline D. bryoniae NY3 & Muskmelon & New York (7) \\
\hline D. bryoniae WI1 & Muskmelon & Wisconsin \\
\hline D. bryoniae FL2 & Watermelon & Florida \\
\hline D. bryoniae NY4 & Watermelon & New York \\
\hline D. bryoniae NY5 & Watermelon & New York (7) \\
\hline D. bryoniae W73 & Watermelon & South Carolina \\
\hline D. bryoniae W74 & Watermelon & South Carolina \\
\hline D. bryoniae W95 & Watermelon & South Carolina \\
\hline D. bryoniae W99 & Watermelon & South Carolina \\
\hline D. bryoniae W100 & Watermelon & South Carolina \\
\hline D. bryoniae W101 & Watermelon & South Carolina \\
\hline D. bryoniae W103 & Watermelon & South Carolina \\
\hline \multicolumn{3}{|l|}{ RAPD group II } \\
\hline D. bryoniae NY8 & Butternut squash & New York (2) \\
\hline D. bryoniae NY9 & Butternut squash & New York (3) \\
\hline D. bryoniae NY15 & Butternut squash & New York (7) \\
\hline D. bryoniae NY16 & Butternut squash & New York (7) \\
\hline D. bryoniae NY10 & Cucumber & New York (7) \\
\hline D. bryoniae NY11 & Cucumber & New York (7) \\
\hline D. bryoniae AZ1 & Muskmelon & Arizona \\
\hline D. bryoniae NY13 & Muskmelon & New York (7) \\
\hline D. bryoniae NY14 & Muskmelon & New York (7) \\
\hline D. bryoniae NY7 & Pumpkin & New York (1) \\
\hline D. bryoniae NY12 & Pumpkin & New York (5) \\
\hline D. bryoniae NY17 & Pumpkin & New York (7) \\
\hline \multicolumn{3}{|l|}{ RAPD group III } \\
\hline Phoma sp. NY18 & Butternut squash & New York (3) \\
\hline Phoma sp. C63 & Cucumber & South Carolina \\
\hline Phoma sp. C65 & Cucumber & South Carolina \\
\hline Phoma sp. C67 & Cucumber & South Carolina \\
\hline Phoma sp. C73 & Cucumber & South Carolina \\
\hline Phoma sp. C75 & Cucumber & South Carolina \\
\hline Phoma sp. NC1 & Cucumber & North Carolina (8) \\
\hline Phoma sp. NC2 & Cucumber & North Carolina (9) \\
\hline Phoma sp. NY19 & Cucumber & New York (1) \\
\hline Phoma sp. C55 & Muskmelon & South Carolina \\
\hline Phoma sp. NY20 & Muskmelon & New York (6) \\
\hline Phoma sp. NY21 & Muskmelon & New York (4) \\
\hline Phoma sp. W97 & Watermelon & South Carolina \\
\hline \multicolumn{3}{|l|}{ RAPD group IV } \\
\hline D. bryoniae NY22 & Muskmelon & New York (7) \\
\hline \multicolumn{3}{|l|}{ RAPD group not tested ${ }^{c}$} \\
\hline P. medicaginis ATCC 64481 & Unknown & ATCC \\
\hline P. exigua АТСC 14728 & Unknown & ATCC \\
\hline
\end{tabular}

a Isolates in bold type were used for sequencing ITS-1 and ITS-2 regions.

b The Florida isolates were from Collier County. The New York isolates were from (1) Albany, (2) Montgomery, (3) Oneida, (4) Onondaga, (5) Ontario, (6) Schoharie, and (7) Tompkins counties. The North Carolina isolates were from (8) Clinton and (9) Duplin counties. The South Carolina isolates were from Charleston County.

c Isolates not included in RAPD analysis.
Genomic DNA isolation. Mycelium of all isolates grown on QPDA in the dark at $23^{\circ} \mathrm{C}$ was scraped from agar plates, added to sucrose-casein-salts liquid medium (15), and grown as described previously (12). Cultures were decanted through cheesecloth, and mycelium was washed with water. After as much water as possible was squeezed out, $1.0 \mathrm{~g}$ of mycelium was frozen in liquid nitrogen before being stored at $-80^{\circ} \mathrm{C}$. DNA was extracted according to a standard protocol using $5 \mathrm{ml}$ of lysis buffer and corresponding amounts of other reagents (14). The DNA precipitate was spooled with a hooked glass rod, washed in $70 \%$ ethanol, and resolubilized in sterile deionized water. The DNA concentration was determined with a fluorometer (Hoefer TKO 100) and adjusted to $10 \mathrm{ng} / \mu \mathrm{l}$.

RAPD assays. Commercial RAPD 10-mer oligonucleotide primers were purchased from Operon Technologies (Alameda, California). PCR amplification was performed in a Perkin-ElmerCetus thermal cycler (Norwalk, Connecticut) using $40 \mathrm{ng}$ of genomic DNA, as described previously (12). All RAPD reactions were repeated at least once to verify reproducibility.

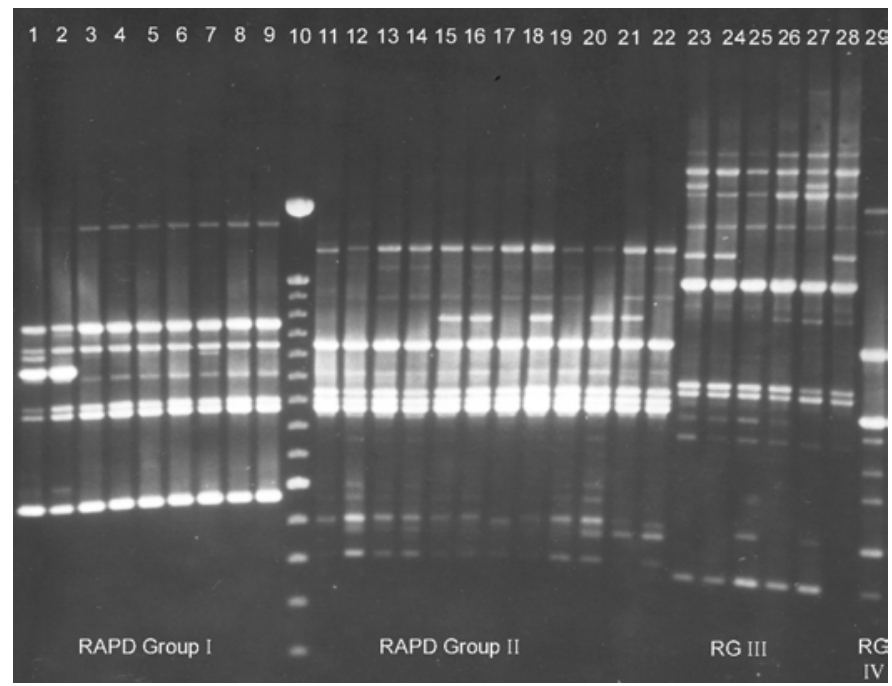

Fig. 1. Random amplified polymorphic DNA (RAPD) fingerprints of nine isolates of Didymella bryoniae from Florida, Wisconsin, and New York (lanes 1 to 9, RAPD group I), 12 isolates of D. bryoniae from Arizona and New York (lanes 11 to 22, RAPD group II), six isolates of Phoma spp. from North Carolina and New York (lanes 23 to 28, RAPD group III), and D. bryoniae NY22 (lane 29, RAPD group IV) amplified with Operon primer OPK-4. Lane 10 is a 100-bp marker.

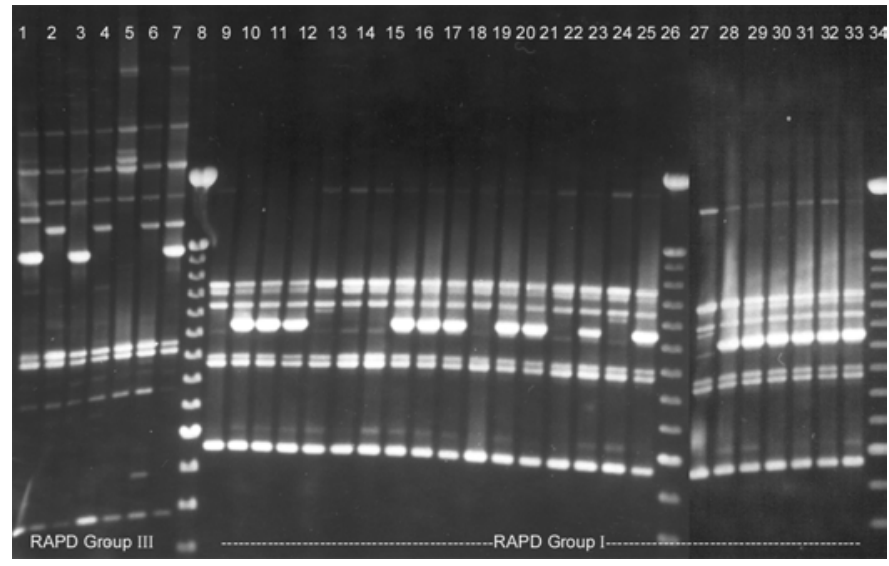

Fig. 2. Random amplified polymorphic DNA (RAPD) fingerprints of isolates of Phoma spp. (lanes 1 to 7, RAPD group III) and Didymella bryoniae (lanes 9 to 25 and 27 to 33, RAPD group I) from South Carolina amplified with Operon primer OPK-4. Lanes 8, 26, and 34 are 100-bp markers. 
Amplification of ITS-1 and ITS-2 regions. The ITS repeat region of rDNA (ITS-1 region, 5.8S gene, and ITS-2 region) was amplified using universal PCR primers from 37 isolates, including 12 in RAPD group (RG) I, 12 in RG II, and 10 in RG III plus NY22 (RG IV), Phoma medicaginis ATCC 64481, and P. exigua ATCC 14728 (Table 1). The sequences of the primers, synthesized by Integrated DNA Technologies (Coralville, Iowa), were TCCTCCGCTTATTGATATGC (ITS-4) and GGAAGTAAAAGTCGTAACAAGG (ITS-5) (32). PCR mixtures were similar to that of the RAPD reactions except that the concentration of deoxynucleoside triphosphate (dNTP) was decreased to $50 \mu \mathrm{M}, 20 \mathrm{ng}$ of each of the ITS4 and ITS5 primers was used, and reagents were adjusted accordingly for a $50-\mu \mathrm{l}$ reaction volume. Thermal cycling was initiated by denaturation at $94^{\circ} \mathrm{C}$ for $1 \mathrm{~min}$. This was followed by 30 cycles of denaturation at $94^{\circ} \mathrm{C}$ for $1 \mathrm{~min}$, annealing at $65^{\circ} \mathrm{C}$ for $1 \mathrm{~min}$, and extension at $72^{\circ} \mathrm{C}$ for $2 \mathrm{~min}$. At the end of 30 cycles, a final extension at $72^{\circ} \mathrm{C}$ for $10 \mathrm{~min}$ was performed. Samples were cooled and stored at $4^{\circ} \mathrm{C}$ until use. The entire $50-\mu \mathrm{l}$ sample was loaded into a $1 \%$ agarose gel and subjected to electrophoresis.

Cloning and sequencing of ITS PCR products. PCR fragments were excised from agarose gels, macerated, frozen at $-80^{\circ} \mathrm{C}$ for $20 \mathrm{~min}$, and centrifuged in a microcentrifuge for $10 \mathrm{~min}$ (freeze-squeeze). The supernatant was removed, and each PCR fragment was individually ligated into the pGem T-easy plasmid cloning vector (Promega) at $4^{\circ} \mathrm{C}$ overnight. Ligated DNA was electroporated into electrocompetent Escherichia coli HB101 cells by the use of a Cell Porator electroporator (Gibco BRL, Grand
Island, New York). Plasmid DNA was isolated from clones by the use of a Wizard Plus plasmid DNA purification kit (Promega). Inserts were released from plasmid clones by digestion with $E c o$ RI and blotted onto nylon membranes. Positive clones were identified by Southern hybridization. Between 50 and $100 \mathrm{ng}$ of probe DNA was radiolabeled with ${ }^{32} \mathrm{P}$-dCTP by random-primed labeling (Multiprime DNA labeling system, Amersham, Arlington Heights, Illinois). DNA probes were hybridized to membranebound DNA at $65^{\circ} \mathrm{C}$ overnight (23). Filters were washed with $0.1 \times \mathrm{SSC}(15 \mathrm{mM} \mathrm{NaCl}$ plus $1.5 \mathrm{mM}$ sodium citrate) and $0.1 \%$ sodium dodecyl sulfate at $65^{\circ} \mathrm{C}$ for 20 to $30 \mathrm{~min}$ and then were exposed to Kodak X-o-mat autoradiography film at $-80^{\circ} \mathrm{C}$ to identify positive clones. For every PCR product cloned, two random clones were chosen for sequencing. All clones were sequenced in both the forward and the reverse directions, by the use of the M13 forward and reverse primers and an ABI fluorescent dye-terminator cycle sequencing ready reaction kit (Perkin Elmer). To verify the sequencing results, approximately 30 to $100 \mathrm{ng}$ of each PCR fragment was also sequenced directly, by the use of either primer ITS- 4 or primer ITS-5. The ITS- 1 and ITS- 2 regions of the PCR fragments were identified by comparing each of the consensus sequences with known ITS- 1 and ITS- 2 sequences of ascomycete fungi obtained after BLAST searches (1).

Phylogenetics. Data obtained from RAPD fingerprinting and from ITS sequencing were independently used for deriving phylogenetic inferences. For each RAPD primer profile, all isolates were visually compared for the presence or absence of RAPD bands of the same size, scored as 1 and 0 , respectively. Informa-

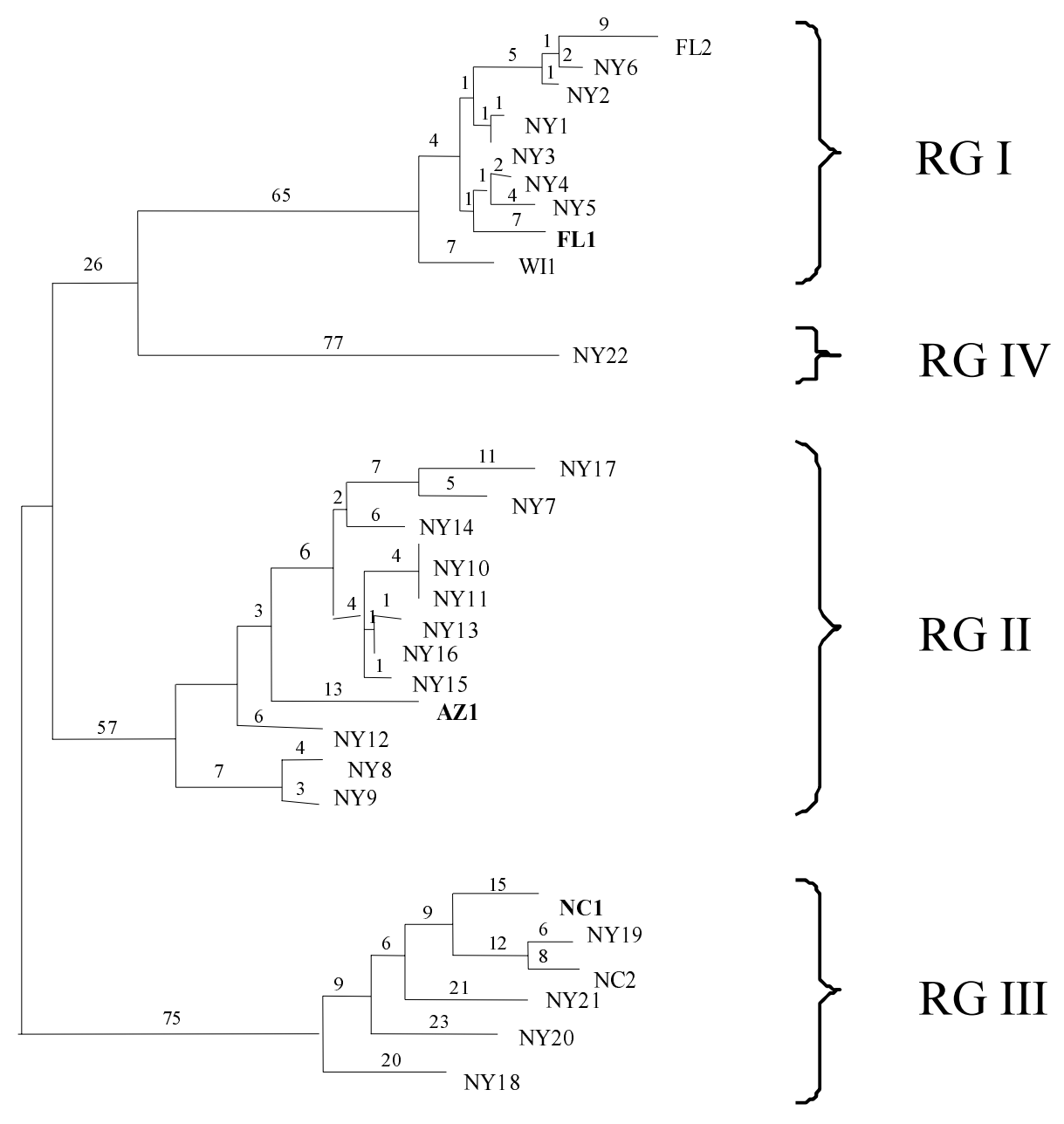

Fig. 3. Results of Phylogenetic Analysis Using Parsimony (PAUP) based on the random amplified polymorphic DNA (RAPD) fingerprints of isolates of Didymella bryoniae and Phoma from New York (NY), Florida (FL), North Carolina (NC), Wisconsin (WI), and Arizona (AZ). Reference isolates (in bold type) are NC1 in RAPD group (RG) III, FL1 in RG I, and AZ1 in RG II. 
tion on banding profiles from all primers used in this study was utilized to determine the genetic distances between isolates and to construct a dendogram. For cluster analysis of RAPD data, owing to the difficulty in visually comparing band sizes from different gels, the South Carolina isolates were analyzed separately from the remaining isolates. However, isolates FL1, AZ1, and NC1, belonging to RAPD groups I, II, and III, respectively, were used to correlate results from the two groups of isolates. ITS sequences from individual isolates were analyzed by Geneworks (release 2.3, Intelligenetics, Mountain View, California), and a consensus sequence was obtained for each RAPD group. ITS-1 and ITS-2 consensus sequences were aligned for each RAPD group. RAPD and ITS data were analyzed by Phylogenetic Analysis Using Parsimony (PAUP, version 3.1.1, Smithsonian Institution, Washington, D.C.). Aligned ITS-1 and ITS-2 sequences were analyzed separately.

Pathogenicity tests. Three isolates chosen to represent RG I (FL1, NY3, and NY5), three from RG II (NY8, NY13, and NY14), and three from RG III (NY18, NY20, and NY21) plus the single isolate in RG IV (NY22), for a total of 10 isolates, were assayed for pathogenicity to 1-week-old seedlings of muskmelon (Cucumis melo cv. Classic), as described previously (12). Each test had a completely randomized design with three replicate pots, $10-\mathrm{cm}$ in diameter, and three seedlings per pot for each isolate. Uninoculated control plants were sprayed with a sterile sucrose- casein solution. Isolate W21, a Phoma sp. nonpathogenic to muskmelon, was included as a negative inoculation control treatment (12). The pathogenicity test was performed twice. The tests were conducted in a reach-in growth chamber maintained at $24^{\circ} \mathrm{C}$. A humidifier was placed in the chamber to provide relative humidity above $90 \%$. Disease severity was rated daily, from the day after inoculation to the sixth day after inoculation, on a scale of $1(0 \%$ of leaf area diseased) to 12 (100\% of leaf area diseased) (8). Once disease ratings were complete, diseased leaves were cultured on QPDA to reisolate the fungi with which the seedlings had been inoculated. Disease ratings were converted to percentage leaf surface area diseased using the midpoint percentage. Data were analyzed by the use of the general linear model of SAS (SAS Institute, Cary, NC), and means were compared with Fisher's protected least significant difference test.

\section{RESULTS}

RAPD analysis. Of the 38 primers from the Operon $\mathrm{T}$ and $\mathrm{K}$ kits that were initially screened, 36 primers (95\%) gave polymorphic bands. For RAPD analysis, we used the 10 random primers that gave the greatest number of polymorphic bands. These 10 primers were OPK-1, OPK-4, OPK-8, OPK-9, OPT-01, OPT-07, OPT-12, OPT-13, OPT-14, and OPT-18; sequences can be obtained from Operon Technologies. On average, five to 10 RAPD

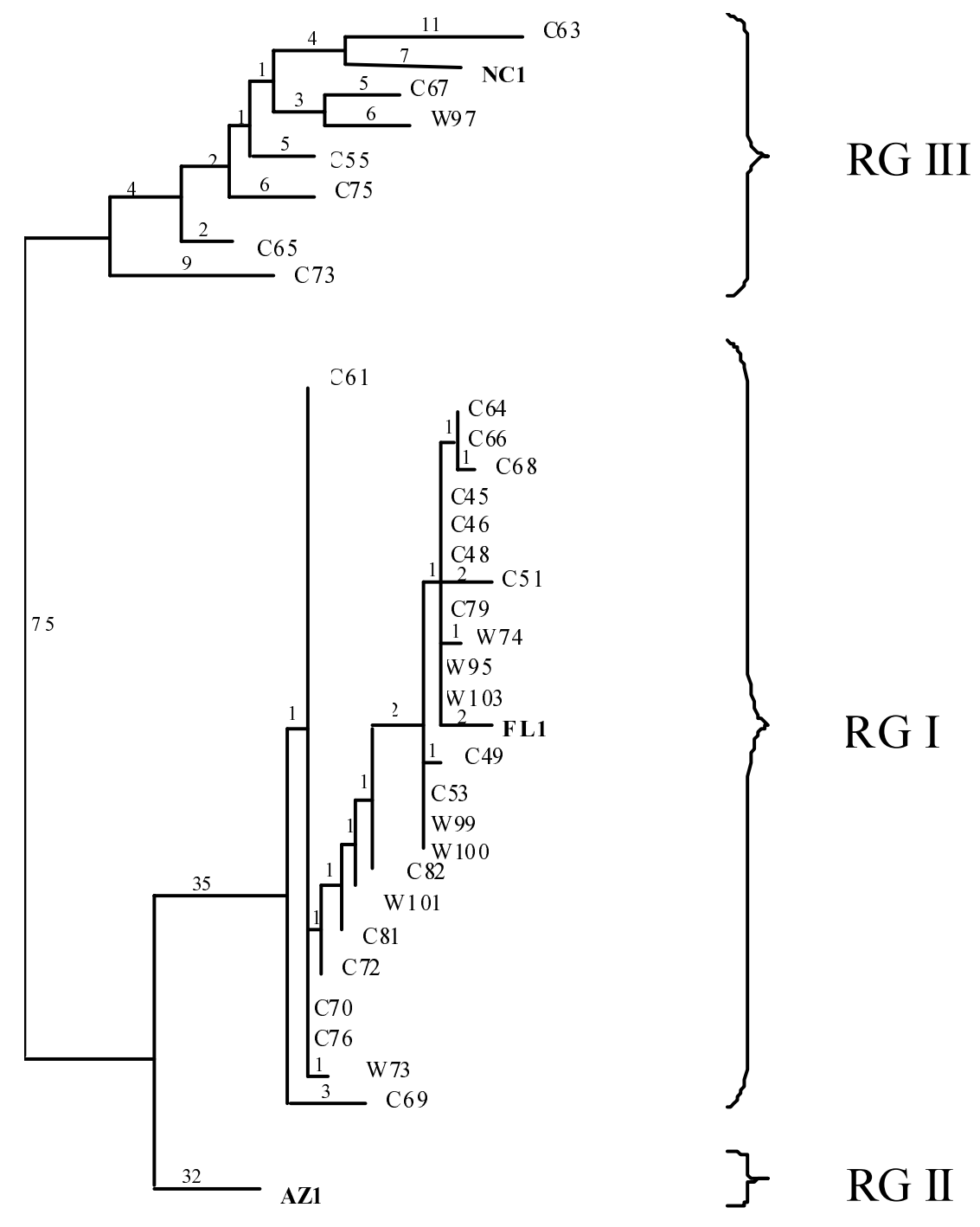

Fig. 4. Results of Phylogenetic Analysis Using Parsimony (PAUP) based on the random amplified polymorphic DNA (RAPD) fingerprints of isolates of Didymella bryoniae and Phoma from South Carolina. Reference isolates (in bold type) are NC1 in RAPD group (RG) III, FL1 in RG I, and AZ1 in RG II. 
bands were generated for each of the 10 primers. Visual evaluation of RAPD profiles indicated that the 59 isolates examined could be placed in four RAPD groups. Thirty-three isolates identified as D. bryoniae on the basis of morphology had identical banding patterns and were placed in a distinct RAPD group, RG I (Figs. 1 and 2). RG I contained 24 isolates from South Carolina, six isolates from New York, two isolates from Florida, and one isolate from Wisconsin (Table 1). Eleven isolates from New York and one isolate from Arizona, also identified as D. bryoniae, had very similar banding patterns that were distinct from those of isolates in RG I, and they were placed in RG II. Thirteen isolates (seven from South Carolina, four from New York, and two from North Carolina) were placed in RG III. One isolate, NY22, always exhibited a RAPD profile unlike any others and was therefore placed in RG IV. These four distinct RAPD groups occurred with every one of the 10 primers; each group contained the same isolates, regardless of which primer was used. Isolates of $D$. bryoniae assigned to RG I, II, and IV could not be distinguished by colony morphology, production of pycnidia or pseudothecia, or conidial shape or septation.

Estimation of evolutionary distance using PAUP supported the assignment of isolates to the RAPD groups. Of the 59 isolates examined in this study, 33 D. bryoniae isolates clustered in RG I, 12 clustered in RG II, and 13 clustered in RG III (Figs. 3 and 4). D. bryoniae NY22 was the only isolate assigned to RG IV. Bootstrap analysis of the data supported the separation of $D$. bryoniae and Phoma isolates in the RAPD groups (bootstrap value 100\%). All isolates in RG I, particularly the South Carolina isolates collected from one farm, were tightly grouped together, as indicated by the short branch lengths (Fig. 4). Isolates in RG II and RG III were less tightly grouped together.

ITS sequence analysis. The ITS -4 and ITS -5 primers uniformly amplified a fragment of approximately 500 bp from 35 representative isolates from RG I, RG II, RG III, and RG IV (Table 1). Sequence analysis revealed that the bands were $522 \mathrm{bp}$ long in the RG III isolates, $526 \mathrm{bp}$ in the RG II and RG IV isolates, and $527 \mathrm{bp}$ in the RG I isolates. Alignment of the consensus sequences indicated that the ITS-1 region of RG I isolates (Gen-

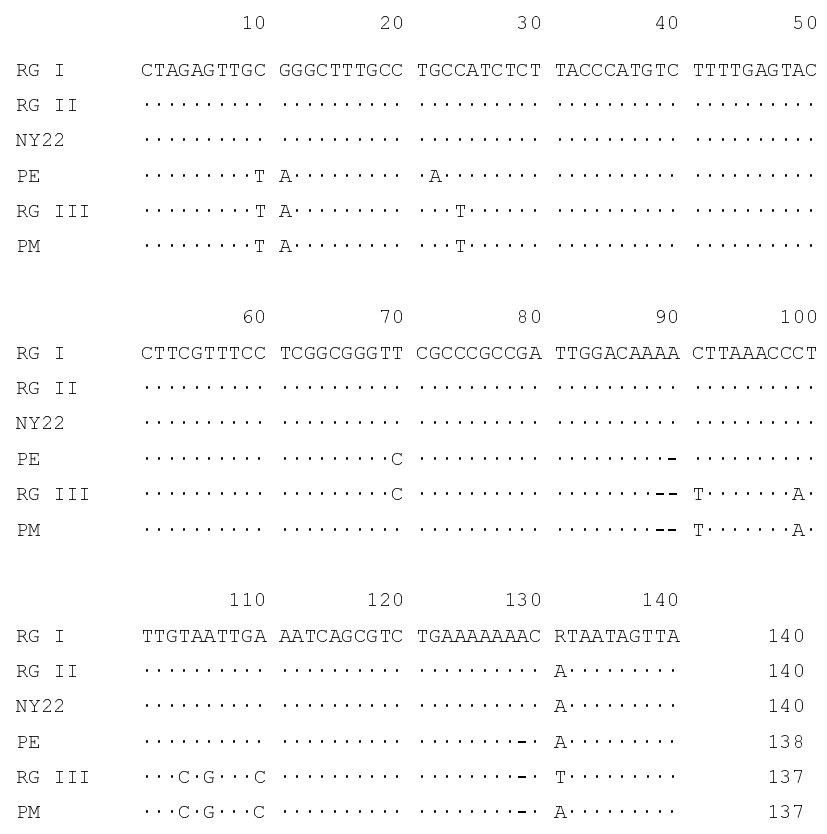

Fig. 5. Computer alignment of the internal transcribed spacer region ITS-1 consensus sequences. RG I = Didymella bryoniae, random amplified polymorphic DNA (RAPD) group I; RG II = Didymella bryoniae, RAPD group II; PE = Phoma exigua ATCC 14728; PM = Phoma medicaginis ATCC 64481; RG III = Phoma, RAPD group III. Dots indicate base similarity, and dashes indicate deletions.
Bank accession number AF495849), RG II isolates, and NY22 was $140 \mathrm{bp}$ long, and, except at position 131, there was complete sequence identity (99.3\% identical) (Fig. 5). At position 131, RG I had a purine (either an adenine or a guanine residue), whereas RG II and NY22 had an adenine residue only. The ITS-1 sequences of RG III isolates (137 bp), P. exigua ATCC 14728 (138 bp), and $P$. medicaginis ATCC 64481 (137 bp) were shorter, because of base deletions in the sequences. Among the ITS-1 sequences of RG I, RG II, and RG III isolates, NY22, P. medicaginis ATCC 64481, and $P$. exigua ATCC 14728, there were 14 base changes, which consisted of 11 substitutions and three deletions.

The ITS-2 sequence of RG I isolates (GenBank accession number AF495850) was $161 \mathrm{bp}$ long, and the remaining sequences were either 159 bp (RG III isolates, P. medicaginis ATCC 64481, and P. exigua ATCC 14728) or 160 bp (RG II isolates and NY22), owing to base deletions (Fig. 6). Each isolate had a unique ITS-2 sequence, i.e., no ITS-2 sequences of any of the isolates were identical. RG I and RG II isolates had the closest sequence identity, except that the sequence from RG II isolates had a deletion at position 153 and was therefore shorter by one base. Among the RG I, RG II, and RG III isolates, NY22, P. medicaginis ATCC 64481, and $P$. exigua ATCC 14728, there were 12 base changes, which consisted of nine substitutions and three deletions.

Phylogenetic analysis of the ITS-1 sequences indicated that RG II isolates and NY22 were identical to RG I isolates (D. bryoniae) (Fig. 7). However, analysis of the ITS-2 sequences indicated that only RG I and RG II isolates were identical and that NY22 was very closely related (one "weighted" character different) (Fig. 8). Phylogenetic analysis of the ITS- 1 and ITS-2 sequences indicated that the RG I, RG II, and RG III isolates and NY22 did not cluster
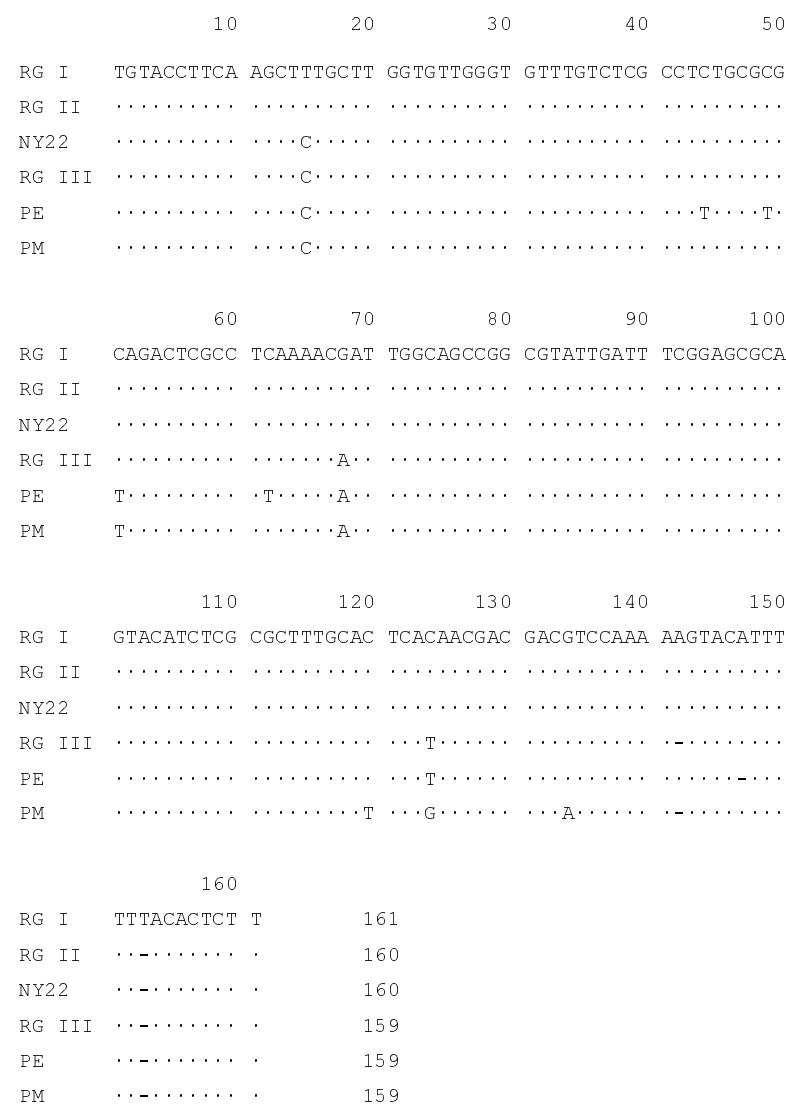

Fig. 6. Computer alignment of the internal transcribed spacer region ITS-2 consensus sequences. RG I = Didymella bryoniae, random amplified polymorphic DNA (RAPD) group I; RG II = Didymella bryoniae, RAPD group II; PE = Phoma exigua ATCC 14728; PM = Phoma medicaginis ATCC 64481; RG III = Phoma, RAPD group III. Dots indicate base similarity, and dashes indicate deletions. 
with either P. exigua or P. medicaginis (Figs. 7 and 8). Of the isolates in the four RAPD groups, those in RG III were most closely related to $P$. medicaginis. RG III isolates were separated from $P$. medicaginis ATCC 64481 by two and four base changes in the ITS-1 and ITS-2 dendrograms, respectively.

Pathogenicity. Of the 10 isolates tested for pathogenicitythree from each of RG I, RG II, and RG III plus one from RG IV (NY22) - only the three D. bryoniae RG I isolates produced severe disease on muskmelon leaves (Table 2). In two independent tests, the mean disease severity for the RG I D. bryoniae isolates was always greater than $65 \%$ (Table 2). The Phoma isolates in RG

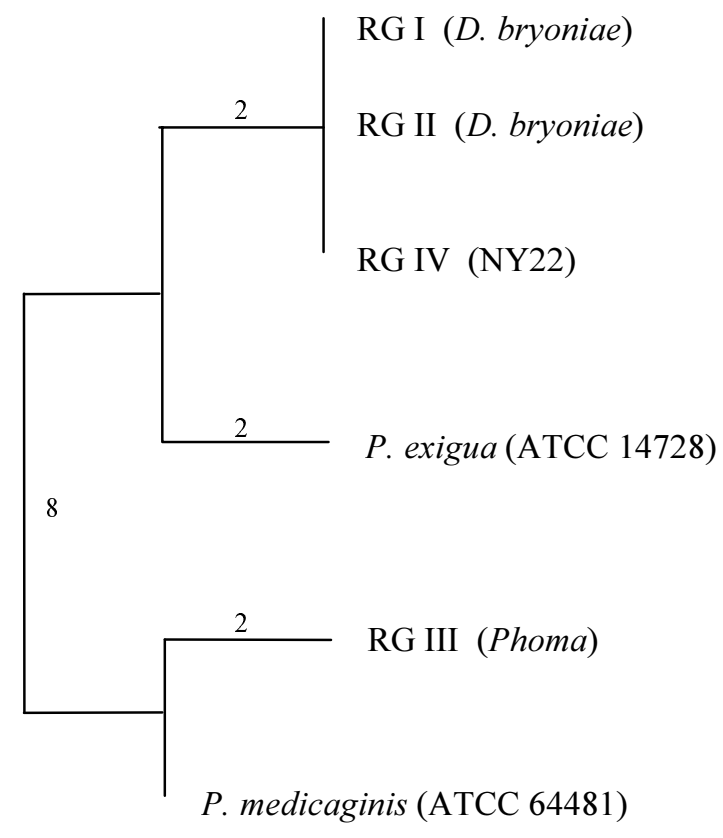

Fig. 7. Phylogenetic groupings of Didymella bryoniae and Phoma spp. based on internal transcribed spacer region ITS-1 sequences. RG = random amplified polymorphic DNA (RAPD) group.

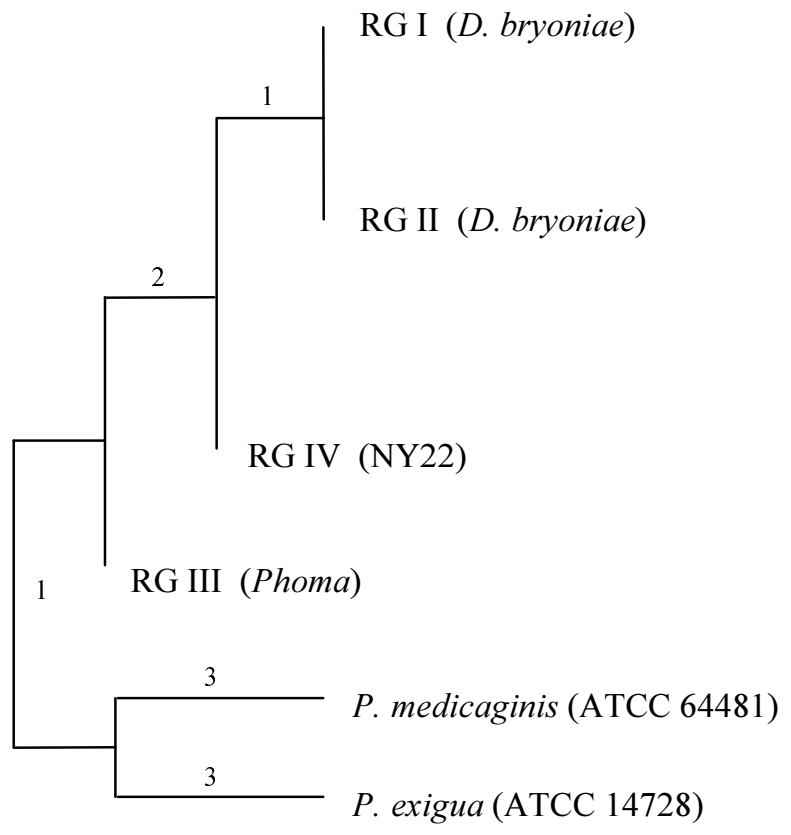

Fig. 8. Phylogenetic groupings of Didymella bryoniae and Phoma spp. based on internal transcribed spacer region ITS-2 sequences. $\mathrm{RD}=$ random amplified polymorphic DNA (RAPD) group.
III were nonpathogenic ( $0 \%$ disease). Phoma isolate W21 was also nonpathogenic. For the RG II isolates and NY22, disease severity ranged from 2.6 to $9 \%$, which is significantly $(P=0.05)$ greater than that of the control treatment and treatment with the RG III isolates but significantly less than that of treatment with the RG I D. bryoniae isolates.

\section{DISCUSSION}

The purpose of this study was to elucidate the genetic relationship between $D$. bryoniae and related Phoma isolates that are often simultaneously isolated from plant material with symptoms of GSB. An earlier study showed the usefulness of RAPD analysis in detecting significant polymorphisms between $D$. bryoniae and Phoma spp. (12). The present study expands on the previous study by using RAPD analysis and ITS sequence analysis on a larger and more diverse collection of isolates to determine their phylogenetic relationships. RAPD analysis of the D. bryoniae and Phoma isolates used in this study subdivided the isolates into four unique sets of genetic fingerprints, RG I, RG II, RG III, and RG IV. The $D$. bryoniae isolates in RG I could easily be identified by comparing their profiles with those observed in a previous study (12). All of the remaining isolates except one exhibited two different yet distinct RAPD fingerprints, RG II and RG III. All of the RG II isolates except one originated from New York. In a previous study, two of three isolates from New York had a RAPD profile different from other D. bryoniae isolates (12). The present sampling of a larger collection of isolates from New York confirms the previous observation. It therefore appears that two genotypes of $D$. bryoniae may be associated with and isolated from plants exhibiting symptoms of GSB.

RG I isolates of D. bryoniae were pathogenic to muskmelon seedlings, with an average disease severity of $71 \%$, whereas the RG III isolates were nonpathogenic ( $0 \%$ disease severity). This difference in pathogenicity confirms the results of our previous study using different isolates (12). The RG II isolates incited low levels of disease in seedlings, with a mean disease severity of $5 \%$. This level of disease is lower than that recorded in another study with 20 different isolates also assigned to RG I, II, and III (36). However, in that study, RG II isolates were also intermediate in virulence between $D$. bryoniae RG I and Phoma isolates, not only

TABLE 2. Mean disease severity on muskmelon 6 days after inoculation with 11 isolates of Didymella bryoniae and Phoma

\begin{tabular}{|c|c|c|c|}
\hline \multirow[b]{2}{*}{ Isolate } & \multirow[b]{2}{*}{$\begin{array}{l}\text { RAPD } \\
\text { group }^{\text {a }}\end{array}$} & \multicolumn{2}{|c|}{ Disease severity ${ }^{\mathrm{b}}$} \\
\hline & & $\begin{array}{c}\text { Square root } \\
\text { transformation }\end{array}$ & $\begin{array}{c}\text { Back-transformed } \\
\text { value }(\%)\end{array}$ \\
\hline Phoma sp. W21 & $\ldots{ }^{c}$ & 0.12 & 0.1 \\
\hline D. bryoniae NY3 & I & 8.58 & 73.6 \\
\hline D. bryoniae NY5 & I & 8.52 & 72.6 \\
\hline D. bryoniae FL1 & I & 8.24 & 67.9 \\
\hline D. bryoniae NY13 & II & 2.97 & 8.8 \\
\hline D. bryoniae NY8 & II & 1.76 & 3.1 \\
\hline D. bryoniae NY14 & II & 1.60 & 3.0 \\
\hline D. bryoniae NY22 & IV & 1.72 & 2.6 \\
\hline Phoma sp. NY18 & III & 0.00 & 0.0 \\
\hline Phoma sp. NY20 & III & 0.00 & 0.0 \\
\hline Phoma sp. NY21 & III & 0.00 & 0.0 \\
\hline $\operatorname{LSD}_{0.05}{ }^{\mathrm{d}}$ & & 1.42 & \\
\hline
\end{tabular}

a Random amplified polymorphic DNA group.

${ }^{b}$ Mean percentage leaf surface area with symptoms of gummy stem blight, averaged across three replications in each of two experiments. For an uninoculated control, disease severity values were 0.00 (square root transformed) and $0.0 \%$ (back-transformed).

${ }^{c}$ The RAPD group of this isolate was not determined in this study, but it is likely to be in group III (12).

${ }^{d}$ Fisher's protected least significant difference on the square root transformed scale. 
in muskmelon but also in cucumber, watermelon, and pumpkin. Segregation of the isolates into three virulence groups conforms identically to the occurrence of the three main RAPD groups. Therefore, RAPD analysis can be used to identify each virulence group. All isolates of D. bryoniae RG I, II and IV were pathogenic in muskmelon, regardless of their host of origin. This lack of host specificity agrees with that documented in previous studies (5, 12,13,36).

Isolate NY19 (representing RG III) was identified as P. medicaginis by G. Kinsey at the International Mycological Institute (personal communication). Isolate AZ-1 (an RG II isolate) and NY22 (the lone RG IV isolate) could not be positively identified, but potential names for both isolates included $P$. exigua, $P$. cucurbitacearum, and $P$. lycopersici. We therefore included $P$. medicaginis and $P$. exigua as reference cultures during the ITS sequence analysis. NY22 clustered very closely with $D$. bryoniae. However, the ITS sequences exhibited a significant number of base differences between RG III isolates and $P$. medicaginis ATCC 64481 and between RG II isolates and P. exigua ATCC 14728 , suggesting that there was less sequence similarity between RG III isolates and P. medicaginis or between RG II isolates and $P$. exigua. Isolate NY19 has also been classified as $P$. americana $(16,21)$. In another phylogenetic study (21), which used only ITS-1 sequences, NY19 was distinguished from $D$. bryoniae by 10 base changes, similar to the 12 base changes we found using a consensus sequence for 10 Phoma isolates.

ITS sequence data indicated a closer relationship between RG I and RG II than RAPD data did. RAPD analysis includes multiple loci throughout the entire genome and generates multilocus data $(31,34)$. RAPD analysis is capable of distinguishing closely related fungal isolates, such as leaf- and stem-infecting forms of rust fungi on willow (19). The entire genome is subject to faster evolutionary changes than the highly conserved ITS regions, which only evolve slowly (2). Phylogenetic analysis derived from ITS-1 and ITS-2 sequence data grouped $D$. bryoniae isolates in RG I and RG II into a single, common phylogenetic cluster; thus, the two RAPD groups could not be distinguished from each other using these criteria. RG III isolates, on the other hand, clustered separately from $D$. bryoniae isolates in RG I and RG II. This suggests that, phylogenetically, RG III isolates are distantly related to $D$. bryoniae RG I isolates, while RG II isolates are very closely related to D. bryoniae RG I isolates. However, close examination of RG II showed that, although the RAPD banding profiles of these isolates were unique, the profiles often shared many common bands with $D$. bryoniae RG I and Phoma RG III isolates. Parsimony analysis of RAPD data indicated that the evolutionary distance between RG I and RG II was similar to that between RG III and RG II, since branch lengths were almost equal. The simplest explanation for this is that RG I and RG II are genetic subgroups within $D$. bryoniae that are diverging. Because of the long history of cucurbit cultivation in the eastern United States (22), it is possible that the $D$. bryoniae population in New York is diverging from the $D$. bryoniae population in other parts of the United States. A similar hypothesis of divergence from a common ancestor was proposed to explain phylogenetic relationships among the wheat bunt fungi (25).

On the evidence of several results, it is clear that $D$. bryoniae RG I, D. bryoniae RG II, and Phoma RG III represent distinct molecular subgroups. This study identified sequence differences between $D$. bryoniae and Phoma in the ITS-1 and ITS-2 regions. Further, ITS-1 and ITS-2 sequencing and phylogenetic analyses revealed that D. bryoniae RG II isolates shared greater than $99 \%$ sequence similarity with $D$. bryoniae RG I isolates. RAPD profiles, pathogenicity, and virulence data from the current study supported the results obtained in previous studies $(12,36)$. We therefore conclude that RG I and RG II isolates are both D. bryoniae, but that they represent two different molecular and virulence subgroups.

\section{LITERATURE CITED}

1. Altschul, S. F., Madden, T. L., Schäffer, A. A., Zhang, J., Zhang, Z., Miller, W., and Lipman, D. J. 1997. Gapped BLAST and PSI-BLAST: A new generation of protein database search programs. Nucleic Acids Res. 25:3389-3402.

2. Bruns, T. D., White, T. J., and Taylor, J. W. 1991. Fungal molecular systematics. Annu. Rev. Ecol. Syst. 22:525-564.

3. Bryan, G. T., Daniels, M. J., and Osbourn, A. E. 1995. Comparison of fungi within the Gaeumannomyces-Phialophora complex by analysis of ribosomal DNA sequences. Appl. Environ. Microbiol. 61:681-689.

4. Chiu, W. F., and Walker, J. C. 1949. Morphology and variability of the cucurbit black rot fungus. J. Agric. Res. 78:81-102.

5. Chiu, W. F., and Walker, J. C. 1949. Physiology and pathogenicity of the cucurbit black-rot fungus. J. Agric. Res. 78:589-615.

6. Corlett, M. 1981. A taxonomic survey of some species of Didymella and Didymella-like species. Can. J. Bot. 59:2016-2042.

7. Farr, D. F., Bills, G. F., Chamuris, G. P., and Rossman, A. Y. 1989. Fungi on Plants and Plant Products in the United States. American Phytopathological Society, St. Paul, MN.

8. Horsfall, J. G., and Barratt, R. W. 1945. An improved system for measuring plant diseases. (Abstr.). Phytopathology 35:655.

9. Hseu, R. S., Wang, H. H., Wang, H. F., and Moncalvo, J. M. 1996. Differentiation and grouping of isolates of the Ganoderma lucidum complex by random amplified polymorphic DNA-PCR compared with grouping on the basis of internal transcribed spacer sequences. Appl. Environ. Microbiol. 62:1354-1363.

10. Jenkins, S. F., Jr., and Person, L. H. 1973. Ascochyta blight of cucurbits caused by Ascochyta phaseolorum. (Abstr.) Phytopathology 63:444.

11. Kaiser, W. J., Wang, B.-C., and Rogers, J. D. 1997. Ascochyta fabae and A. lentis: Host specificity, teleomorphs (Didymella), hybrid analysis, and taxonomic status. Plant Dis. 81:809-816.

12. Keinath, A. P., Farnham, M. W., and Zitter, T. A. 1995. Morphological, pathological and genetic differentiation of Didymella bryoniae and Phoma spp. isolated from cucurbits. Phytopathology 85:364-369.

13. Lee, D.-H., Mathur, S. B., and Neergard, P. 1984. Detection and location of seed-borne inoculum of Didymella bryoniae and its transmission in seedlings of cucumber and pumpkin. Phytopathol. Z. 109:301-308.

14. Lee, S. B., Milgroom, M. G., and Taylor, J. W. 1988. A rapid, high yield mini-prep method for isolation of total genomic DNA from fungi. Fungal Genet. Newsl. 35:23-24.

15. Maiero, M., Bean, G. A., and Ng, T. J. 1991. Toxin production by Alternaria solani and its related phytotoxicity to tomato breeding lines. Phytopathology 81:1030-1033.

16. Morgan-Jones, G., and White, J. F. 1983. Studies in the genus Phoma. I. Phoma americana sp. nov. Mycotaxon 16:403-413.

17. Norton, J. D., and Cosper, R. D. 1989. AC-70-154, a gummy stem blight resistant muskmelon breeding line. HortScience 24:709-711.

18. Norton, J. D., Cosper, R. D., Smith, D. A., and Rymal, K. S. 1986. AUJubilant and AU-Producer watermelons. HortScience 21:1460-1461.

19. Pei, M. H., Whelan, M. J., Halford, N. G., and Royle, D. J. 1997. Distinction between stem- and leaf-infecting forms of Melampsora rust on Salix viminalis using RAPD markers. Mycol. Res. 101:7-10.

20. Punithalingam, E., and Holliday, P. 1972. Didymella bryoniae. No. 332 in: Descriptions of Pathogenic Fungi and Bacteria. Commonw. Mycol. Inst., Kew, England.

21. Reddy, P. V., Patel, R., White, J. F., Jr. 1998. Phylogenetic and developmental evidence supporting reclassification of cruciferous pathogens Phoma lingam and Phoma wasabiae in Plenodomus. Can. J. Bot. 76: 1916-1922.

22. Robinson, R. W., and Decker-Walters, D. S. 1997. Cucurbits. CAB International, Wallingford, UK.

23. Sambrook, J., Fritsch, E. F., and Maniatis, T. 1989. Molecular Cloning: A Laboratory Manual. 2nd ed. Cold Spring Harbor Laboratory Press, Cold Spring Harbor, NY.

24. Schenck, N. C. 1968. Epidemiology of gummy stem blight (Mycosphaerella citrullina) on watermelon: Ascospore incidence and disease development. Phytopathology 58:1420-1422.

25. Shi, Y. L., Loomis, P., Christian, D., Carris, L. M., and Leung, H. 1996. Analysis of the genetic relationships among the wheat bunt fungi using RAPD and ribosomal DNA markers. Phytopathology 86:311-318.

26. Sitterly, W. R. 1972. Breeding for disease resistance in cucurbits. Annu. Rev. Phytopathol. 10:471-490.

27. Sitterly, W. R., and Keinath, A. P. 1996. Gummy stem blight. Pages 2728 in: Compendium of Cucurbit Diseases. T. A. Zitter, D. L. Hopkins, and C. E. Thomas, eds. American Phytopathological Society, St. Paul, $\mathrm{MN}$.

28. St. Amand, P. C., and Wehner, T. C. 1995. Eight isolates of Didymella bryoniae from geographically diverse areas exhibit variation in virulence 
but no isolate by cultivar interaction on Cucumis sativus. Plant Dis. 79:136-1139.

29. Sumner, D. R., and Phatak, S. C. 1987. Control of foliar diseases of cucumber with resistant cultivars and fungicides. Appl. Agric. Res. 2:324329.

30. Wehner, T. C., and St. Amand, P. C. 1993. Field tests for cucumber resistance to gummy stem blight in North Carolina. HortScience 28:327-329.

31. Welsh, J., and McClelland, M. 1990. Fingerprinting genomes using PCR with arbitrary primers. Nucleic Acids Res. 18:7213-7218.

32. White, T. J., Bruns, T., Lee, S., and Taylor, J. 1990. Amplification and direct sequencing of fungal ribosomal RNA genes for phylogenetics. Pages 315-322 in: PCR Protocols: A Guide to Methods and Applications. M. A. Innis, D. H. Gelfand, J. J. Sninsky, and T. J. White, eds. Academic
Press, San Diego, CA.

33. Wiant, J. S. 1945. Mycosphaerella black rot of cucurbits. J. Agric. Res. 71:193-213.

34. Williams, J. G. K., Kubelik, A. R., Livak, K. J., Rafalski, J. A., and Tingey, S. V. 1990. DNA polymorphisms amplified by arbitrary primers are useful as genetic markers. Nucleic Acids Res. 18:6531-6535.

35. Zhang, A. W., Hartman, G. L., Riccioni, L., Chen, W. D., Ma, R. Z., and Pedersen, W. L. 1997. Using PCR to distinguish Diaporthe phaseolorum and Phomopsis longicolla from other soybean fungal pathogens and to detect them in soybean tissues. Plant Dis. 81:1143-1149.

36. Zuniga, T. L. 1999. Gummy stem blight (Didymella bryoniae) of cucurbits: Pathogen characterization and inheritance of resistance in melon (Cucumis melo). Ph.D. dissertation, Cornell University, Ithaca, NY. 